«Системні технологіï» 6 (125) 2019 «System technologies»

DOI 10.34185/1562-9945-6-125-2019-04

UDC 629.78

Anatolii Alpatov, Erik Lapkhanov

\title{
THE USE OF MOBILE CONTROL METHODS FOR STABILIZATION OF A SPACECRAFT WITH AEROMAGNETIC DEORBITING SYSTEM
}

Annatation. The search for optimal control algorithms for spacecrafts is one of the key areas in rocket and space technology. Taking into account certain restrictions and requirements in a specific space mission, the selection of certain executive devices of the spacecraft is carried out and the corresponding control law is synthesized. One of such space missions is the providing of angular motion stabilization of a utilized spacecraft with aeromagnetic deorbiting system. The stabilization of spacecraft angular motion is needed for the orientation of aerodynamic element perpendicular to the vector of atmosphere dynamic flux with the aim of increasing of aerodynamic braking force. In this mission, the main optimization criterion is the minimization of the on-board electrical energy consumption which is needed for the control of angular motion. The original construction of the aeromagnetic deorbiting system consists of aerodynamic flat sails element and executive control devices with permanent magnets. However, not all spacecraft can be equipped with additional executive control devices with permanent magnets. That's why with the aim of expansion of aeromagnetic deorbiting system application, using extra source of electromagnetic control executive devices is proposed in this research.

The purpose of the article is the search of the control law which provides minimal consumption of electrical on-board energy by electromagnetic control executive devices during long-term deorbiting mission. For satisfying this criterion of optimization using of mobile control methods to orientate the spacecraft with aeromagnetic deorbiting system are proposed in this investigation. Computer modeling of orbital motion of spacecraft with aeromagnetic deorbiting system show the efficiency of using proposed mobile methods for angular motion control which realized by electromagnetic devices - magnetorquers. It has been showed that because of using mobile control method consumption of on-board electrical energy significantly less than with classical approach. The advantages and disadvantages have been determined.

Key words: aeromagnetic deorbiting system, mobile control methods, spacecraft, magnetorquers.

Introduction. The problem of increasing of space debris fragments in Near-Earth Space became actual last time. This is due to the intensity of the launches of carrier rockets with the significant number of spacecrafts to NearEarth Orbits. Spacecrafts at the end of lifetime, lower stages of carrier rockets

(C) Alpatov A., Lapkhanov E., 2019 
«Системні технологіï» 6 (125) 2019 «System technologies»

are the main source of space debris [1]. So, on November, 2019, about 14598 space debris objects (SDO) were catalogued by NASA [2]. In turn, the highest concentration of SDO is observed in the near circular Low Earths Orbits (LEO) with altitude under $2000 \mathrm{~km}$ and Geosynchronous High elliptical communication orbit up to an altitude of $20000 \mathrm{~km}$ at its apogee [3]. So, many methods and means were developed for decreasing the tendency of SDOs number growth.

Today, there are two main approaches of development methods and means for deorbiting of SDO. The first approach is based on creation of active deorbiting systems (ADS). ADS include space servicing vehicles, propulsion deorbiting devices, robotic manipulators for capturing of SDO, electromagnetic devices, system "LEOSweep" with ion beam etc. [4]. These systems are needed control during deorbiting operation and consume on-board electrical energy or fuel. Considering the fact of the opportunity of some spacecrafts control systems failure, propulsion and energy systems failure at the end of lifetime, the extra propulsion or electromagnetic ADS can't be used in all deorbiting space missions. As for space servicing vehicles equipped by robotic manipulators, system "LEOSweep", they are required extra launch to SDOs orbits. In turn, extra launches are required a lot of costs and risks, which make this technology of deorbiting expensive nowadays. Paid attention to these disadvantages of ADS the second approach of deorbiting systems creation had been developed. This approach is based on using passive deorbiting systems (PDS) which practically don't require consumption fuel and on-board energy of spacecraft. PDS are aerodynamic deorbiting systems, electrodynamic tether systems, plasmodynamic deorbiting systems and solar sails. However, when using PDS the process of deorbiting takes a long time. That's why, there are some difficulties which are connected with PDSs reliability assurance during longtime missions. Moreover, some PDS require significant mass and volume for providing the efficiency of their usage. For example, aerodynamic inflatable deorbiting systems requires extra boost system for inflating and deployment, which takes extra useful volume of spacecrafts. Furthermore, during longtime exploitation casing of inflatable element is influenced by space environment factors (atomic oxygen, atmospheric electricity, etc.) which can 
«Системні технологіï» 6 (125) 2019 «System technologies»

damage the casing. From the other hand, there is aerodynamic deorbiting deployable sailing systems which don't need extra boost system and less affected by the space environment. But, unlike inflatable deorbiting systems, the high effectiveness of deployable sailing systems is achieved when aerodynamic sailing element is orientated perpendicular to the vector of atmosphere dynamic flux, which increases the aerodynamic braking force.

Analysis of previous researches. Considering these advantages and disadvantages of ADS and PDS the new approach of development hybrid deorbiting systems was proposed [5-8]. One of these systems is aeromagnetic deorbiting system (AMDS) which consists of two modules: aerodynamic flat sailing element and electromagnetic control system [7]. In the first modification electromagnetic control system AMDS consists of rotational permanent magnets and step electrical engines which rotate these magnets for change the polarity. The study shows that the consumption of electrical energy when using this control systems significant less than using electromagnets [7]. But it can be signed, that low consumption of on-board electrical energy achieves only with providing rough stabilization of the spacecraft. The maximum yaw and pitch deviation of rough stabilization of aerodynamic sails element is 0.2 radian. So, providing of this rough stabilization of aerodynamic flat sailing element makes possible to reduce deorbiting time by $20-30 \%$.

However, not all spacecrafts can be equipped by these control systems on rotational permanent magnets in cause of require of extra protective screens for equipment and devices protection from permanent magnetic field before spacecraft lifetime finish. These protective screens are needed extra volume of spacecraft, which can be difficult to provide on small spacecrafts. Considering these difficulties, with the aim of expanding the boundaries of the AMDSs usage it has been proposed to use extra source of spacecrafts magnetorquers for attitude control. The main condition of use the extra source of magnetorquers is providing minimum of on-board electrical energy consumption. That's why, there is the question of searching of the algorithm of control which will provide the minimum energy consumption.

The aim and objectives of the study. The aim of the study is to search the control law for the spacecraft with aerodynamic sailing element 
«Системні технології» 6 (125) 2019 «System technologies»

(aeromagnetic deorbiting system) for stabilization it perpendicularly to the vector of atmosphere dynamic flux with using magnetorquers and minimum on-board electrical energy consumption.

To achieve this aim, the following tasks were set and done:

- to carry out the synthesis of the control law of the attitude motion of spacecraft with aerodynamic flat sailing element using mobile control methods for magnetorquers;

- to carry out the computer modeling for analysis of stabilization quality considering given maximum error;

- to analyze the consumption of on-board electrical energy using mobile control methods for generating control magnetic moment by magnetorquers comparing with classical approach.

Mathematical models of attitude motion of spacecraft. In turn, to describe the attitude motion of the spacecraft we use the coordinate system (CMCS) is connected to the center of mass of the spacecraft, the axes of which coincide with the main central axes of inertia of the spacecraft. For analysis of attitude motion around the center of mass of spacecraft Euler equations are used:

$$
\left.\begin{array}{l}
J_{x} \frac{\mathrm{d} \omega_{x}}{\mathrm{~d} t}+\omega_{y} \omega_{z}\left(J_{z}-J_{y}\right)=M_{x . c o n t .}+\sum M_{x . \text { pert. }} \\
J_{y} \frac{\mathrm{d} \omega_{y}}{\mathrm{~d} t}+\omega_{x} \omega_{z}\left(J_{x}-J_{z}\right)=M_{y . c o n t .}+\sum M_{y . \text { pert. }} \\
J_{z} \frac{\mathrm{d} \omega_{z}}{\mathrm{~d} t}+\omega_{y} \omega_{x}\left(J_{y}-J_{x}\right)=M_{z . \text { cont. }}+\sum M_{z . \text { pert. }}
\end{array}\right\},
$$

where $J_{x}, J_{y}, J_{z}$ - main central moments of inertia of the spacecraft with aerodynamic flat sailing element;

$M_{\text {x.cont. }}, M_{y . \text { cont. }}, M_{z . \text { cont. }}$ - projection of the control magnetic moment on the CMCS axis;

$M_{\text {x.pert. }}, M_{y, \text { pert. }}, M_{z . \text { pert. }}-$ projection of the perturbation moment on the CMCS axis;

$\omega_{x}, \omega_{y}, \omega_{z}-$ the projections of the absolute angular velocity of the spacecraft on the CMCS axis. 
«Системні технології» 6 (125) 2019 «System technologies»

The cinematic equations can be presented in the following form:

$$
\left[\begin{array}{c}
\dot{\psi} \\
\dot{\phi} \\
\dot{\theta}
\end{array}\right]=\frac{1}{\cos \phi}\left[\begin{array}{ccc}
\cos \phi & \sin \phi \sin \psi & \sin \phi \cos \psi \\
0 & \cos \phi \cos \psi & -\sin \psi \cos \phi \\
0 & \sin \psi & \cos \psi
\end{array}\right]\left[\begin{array}{l}
\omega_{x} \\
\omega_{y} \\
\omega_{z}
\end{array}\right],
$$

where $\psi, \phi, \theta$ - Krylov angles (yaw, roll, pitch).

Synthesis of mobile control law for spacecraft with aeromagnetic deorbiting system. For the synthesis of the controller, using the feedback linearization method, it is convenient to represent a nonlinear mathematical model of the relative motion of the spacecraft (1) in the form of a state space in the following discrete form:

$$
\mathrm{X}_{k+1}=A \mathrm{X}_{k}+B \mathrm{U}_{k}+C \xi_{k}
$$

where $\mathrm{X}_{k}=[\psi, \phi, \theta, \dot{\psi}, \dot{\phi}, \dot{\theta}]^{T}-$ state vector on $k$-th control cycle;

$\mathrm{U}_{k}=\left[M_{x . \text { cont }}, M_{y . \text { cont } .}, M_{z . \text { cont. }}\right]^{T}-$ control vector on $k$-th control cycle;

$\xi_{k}=\left[\sum M_{x . \text { pert }}, \sum M_{y . \text { pert }}, \sum M_{z . \text { pert. }}\right]^{T}-$ vector of perturbations on $k$-th control cycle;

$$
\begin{aligned}
A & =\left[\begin{array}{cccccc}
0 & 0 & 0 & 1 & 0 & 0 \\
0 & 0 & 0 & 0 & 1 & 0 \\
0 & 0 & 0 & 0 & 0 & 1 \\
0 & 0 & 0 & 0 & 0 & 0 \\
0 & 0 & 0 & 0 & 0 & 0 \\
0 & 0 & 0 & 0 & 0 & 0
\end{array}\right] \text { - the state matrix; } \\
B & =\left[\begin{array}{ccc}
J_{x}^{-1} & 0 & 0 \\
0 & J_{y}^{-1} & 0 \\
0 & 0 & J_{z}^{-1}
\end{array}\right] \text { - the control matrix; } \\
C & =\left[\begin{array}{ccc}
1 & 0 & 0 \\
0 & 1 & 0 \\
0 & 0 & 1
\end{array}\right]-\text { the matrix of perturbations. }
\end{aligned}
$$

For the synthesis of control law in each channel the pole placement method is proposed in this problem [9-11]. That's why the matrix and the perturbation vector are not taken into account in discrete equation (3). At the same time, these perturbations are taken into account in the model (1). In 
turn, the efficiency of the controller is determined by the bandwidth and the ability to compensate for the disturbance.

So, the linear control vector can be represented as follows:

$$
\mathrm{U}_{k}^{L}=-K \mathrm{X}_{k}
$$

where $K$ - matrix of gain coefficients.

In turn, this matrix of gain coefficients with using binomial distribution can be written as follows:

$$
K=\left[\begin{array}{cccccc}
K_{1} & 0 & 0 & K_{2} & 0 & 0 \\
0 & K_{1} & 0 & 0 & K_{2} & 0 \\
0 & 0 & K_{1} & 0 & 0 & K_{2}
\end{array}\right],
$$

where $K_{1}=\omega_{0}^{2}, K_{2}=2 \cdot \omega_{0}, \omega_{0}$ is the performance of regulator.

Then the linear control moments in each channel are written as follows:

$$
\begin{aligned}
& M_{x . \text { cont.lin. }}=-J_{x}\left(K_{1} \psi+K_{2} \dot{\psi}\right), \\
& M_{y . \text { cont.lin. }}=-J_{y}\left(K_{1} \phi+K_{2} \dot{\phi}\right), \\
& M_{z . c o n t . l i n .}=-J_{z}\left(K_{1} \theta+K_{2} \dot{\theta}\right),
\end{aligned}
$$

where $M_{x . c o n t . l i n,}, M_{y . c o n t . l i n .}, M_{z . c o n t . l i n .}$ - linear control moments in yaw, roll, pitch channels which are generated by linear regulator (4).

The converting from linear model (6) to real nonlinear model is realized with the transformation:

$$
\mathrm{U}_{k}^{N}=\left(J F_{k} J^{-1}\right)^{-1}\left(\mathrm{U}_{k}^{L}-J \dot{F}_{k} \omega_{k}\right)+\omega_{k} \times J \omega_{k},
$$

where $J$ - diagonal matrix of inertia with of the spacecraft with aerodynamic sailing flat element;

$$
\begin{aligned}
\omega_{k} & =\left[\omega_{x}^{F}, \omega_{y}^{F}, \omega_{z}^{F}\right]^{T} ; \\
F_{k} & =\left[\begin{array}{ccc}
1 & \tan \phi_{k} \sin \psi_{k} & \tan \phi_{k} \cos \psi_{k} \\
0 & \cos \psi_{k} & -\sin \psi_{k} \\
0 & \sec \phi_{k} \sin \psi_{k} & \sec \phi_{k} \cos \psi_{k}
\end{array}\right] ;
\end{aligned}
$$




$$
\dot{F}_{k}=\left[\begin{array}{ccc}
0 & {\left[\sec ^{2} \phi_{k} \sin \psi_{k} \dot{\phi}_{k}+\cos \psi_{k} \tan \phi_{k} \dot{\psi}_{k}\right]} & {\left[\sec ^{2} \cos \psi_{k} \phi_{k} \dot{\phi}_{k}-\sin \psi_{k} \tan \phi_{k} \dot{\psi}_{k}\right]} \\
0 & -\sin \phi_{k} \dot{\phi}_{k} & -\cos \psi_{k} \dot{\psi}_{k} \\
0 & {\left[\sec \phi_{k}\left(\sin \psi_{k} \tan \phi_{k} \dot{\phi}_{k}+\cos \psi_{k} \dot{\psi}_{k}\right)\right]} & {\left[\sec \phi_{k}\left(\cos \psi_{k} \tan \phi_{k} \dot{\phi}_{k}-\sin \psi_{k} \dot{\psi}_{k}\right)\right]}
\end{array}\right] .
$$

So, with the transformation (7) the theoretical nonlinear control moments $M_{x . c o n t . n l .}, M_{y . \text { cont.nl. }}, M_{z . c o n t . n l}$ for each channel are generated.

Considering that control devices are magnetorquers, there is the following expression:

$$
\bar{M}_{\text {magn. }}=\bar{p}_{m} \times \bar{B}_{E M F},
$$

where $\bar{p}_{m}$ - vector of magnetic dipole moment of the magnetorquers coils;

$\bar{B}_{E M F}$ - vector of magnetic induction of Earth Magnetic Field (EMF).

Using the methods of mobile control [12, 13], the control law for spacecraft with aeromagnetic system can be synthesized with using 3 main algorithms in the follow form:

$$
\left.\begin{array}{l}
M_{x . \text { cont.nl. }}=M_{\text {magn } . x}=\operatorname{sign}\left(\delta_{y}\right) \cdot p_{m y} \cdot B_{E M F . z} \\
M_{y . \text { cont.nl. }}=M_{\text {magn. } y}=-\operatorname{sign}\left(\delta_{x}\right) \cdot p_{m x} \cdot B_{E M F . z} \\
M_{\text {pert. } . z}=\operatorname{sign}\left(\delta_{x}\right) \cdot p_{m x} \cdot B_{E M F . y}-\operatorname{sign}\left(\delta_{y}\right) \cdot p_{m y} \cdot B_{E M F . x}
\end{array}\right\} \rightarrow \text { control }-I
$$

where control - I, II, III - 3 main algorithms which will be used in mobile control law;

$M_{\text {magn.x }}, M_{\text {magn.y }}, M_{\text {magn.z }}$ - control magnetic moments which are calculated from theoretical nonlinear moments which are generated by nonlinear regulator in CMCS;

$M_{\text {pert.x }}, M_{\text {pert. } y}, M_{\text {pert. } z}$ - moments of perturbations which are accumulated as an error in the third channel when algorithms control - I, II, III are used for magnetorquers in CMCS;

$p_{m x}, p_{m y}, p_{m z}$ - magnetic dipole moments of magnetorquers coils in CMCS; 
«Системні технології» 6 (125) 2019 «System technologies»

$B_{E M F . x}, B_{E M F . y}, B_{E M F . z}$ - projection of the vector $\bar{B}_{E M F}$ on the CMXS axis;

$\delta_{x}, \delta_{y}, \delta_{z}$ - the functions of the sign, which provide necessary polarity of magnetic dipole moments of magnetorquers coils.

In turn, the switch function which change the control - I, II or III at the certain point in time depends on initial maximum error can be written as:

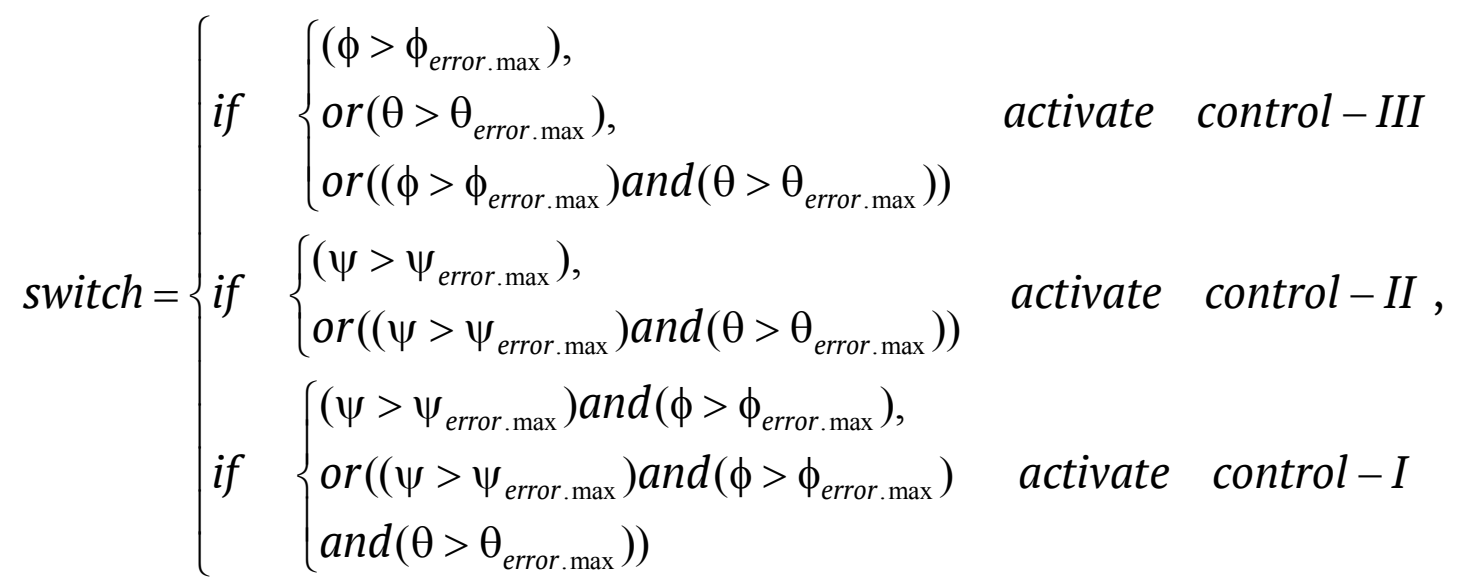

where $\psi_{\text {error.max }}, \phi_{\text {error.max }}, \theta_{\text {error.max }}-$ maximum values of the errors of yaw, roll, pitch.

So, the full algorithm of the synthesized control law presented on the figure 1.

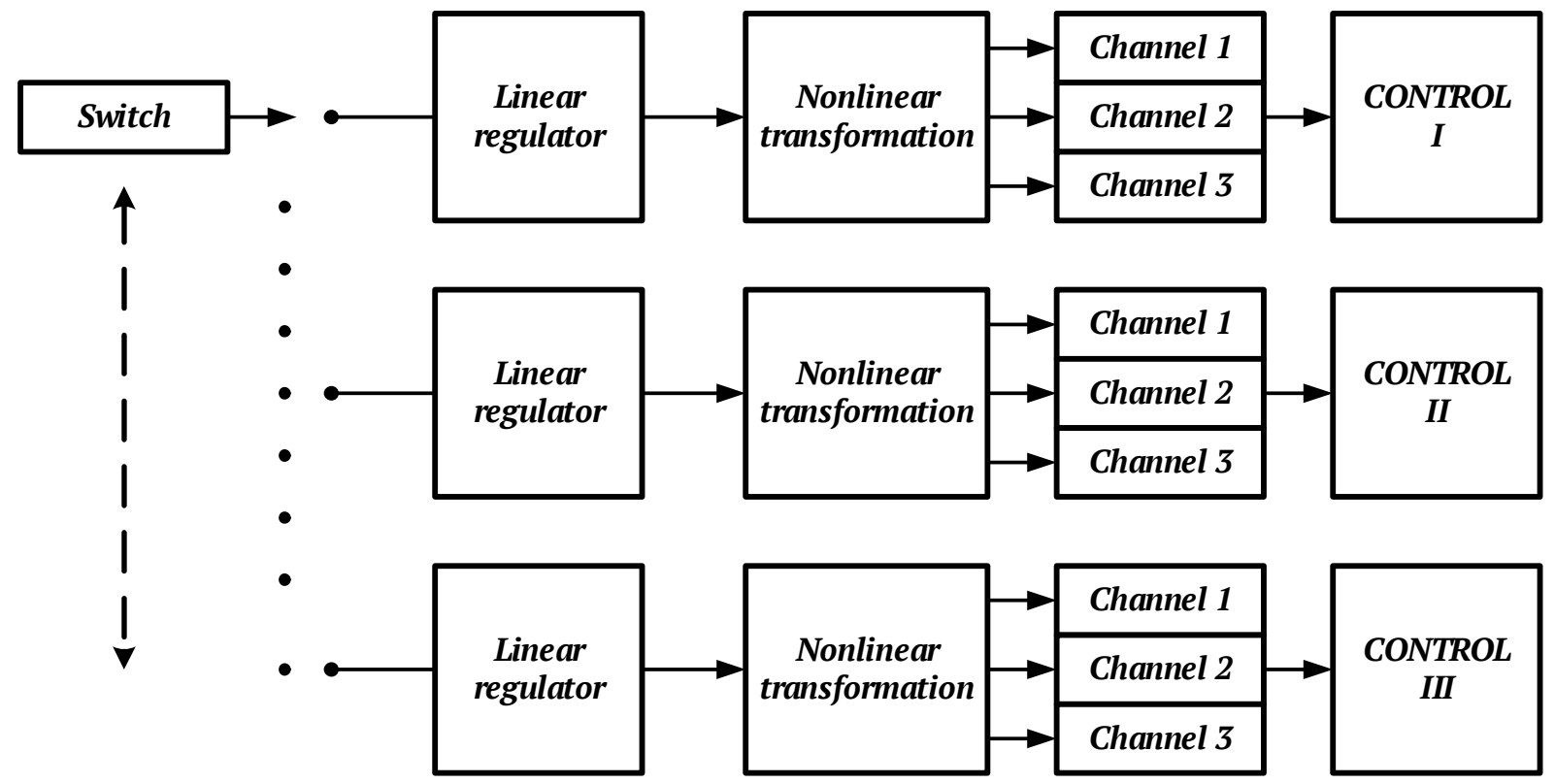

Figure 1 - Mobile control law for spacecraft with aeromagnetic deorbiting system 
«Системні технологіï» 6 (125) 2019 «System technologies»

To analyze sustainability and quality of control and consumptions of electrical on-board energy will be carried out the numerical and computer simulation of attitude spacecraft motion.

Computer simulation. For analysis of using of mobile control law for spacecraft with aeromagnetic deorbiting system the following parameters for simulation are proposed:

- spacecraft mass is $180 \mathrm{~kg}$;

- cross section area of aerodynamic sailing flat element is $5 \mathrm{~m}^{2}$ and mass is $5 \mathrm{~kg}$;

- middles area of spacecraft $0.58 \mathrm{~m}^{2}$;

- $J_{x}=17.995 \mathrm{~kg} \cdot \mathrm{m}^{2}, J_{y}=20.711 \mathrm{~kg} \cdot \mathrm{m}^{2}, J_{z}=15,269 \mathrm{~kg} \cdot \mathrm{m}^{2}$;

- distance from the center of mass to the of pressure is $0.3 \mathrm{~m}$;

- three magnetorquers: model MT30-2 of “ZARM Technik AG” with maximum magnetic dipole moment $30 \mathrm{~A} \cdot \mathrm{m}^{2}$ and mass $1.4 \mathrm{~kg}$.

Orbital translational motion of spacecraft center of mass can be described with the equations in [14] or [15]. So, the orbit with next parameters is chosen for the simulation: eccentricity is 0.0001 ; altitude is $600 \mathrm{~km}$; inclination is 60 degree.

Considering aerodynamic and gravitational perturbations, model [14], formulas (1)-(10) with using atmosphere model [16], the modeling of orbital motion during three axial rough stabilization of spacecraft with aeromagnetic deorbiting system by magnetorquers was carried out. The values of the regulator performance $\omega_{0}$ are 0.012 in each channel. With the maximum value of yaw, roll, pitch errors of 0.2 radian it has been obtained following values of stabilization by each angle for period of $10800 s$ (fig. 2-4).

Based on the analysis of the simulation results (fig. 2-4), it can be concluded that the system remains stable in all three angles at a given control period. Despite the fact that the transition time in some channels is significant (more than $2000 \mathrm{~s}$ ), this satisfies the conditions of rough stabilization in longterm missions. Also, after the transition process, the value of the angles in each channel does not exceed the value of the maximum permissible error of 0.2 radians, which also indicates the stability of the system and acceptable quality of control. 
«Системні технологіï» 6 (125) 2019 «System technologies»

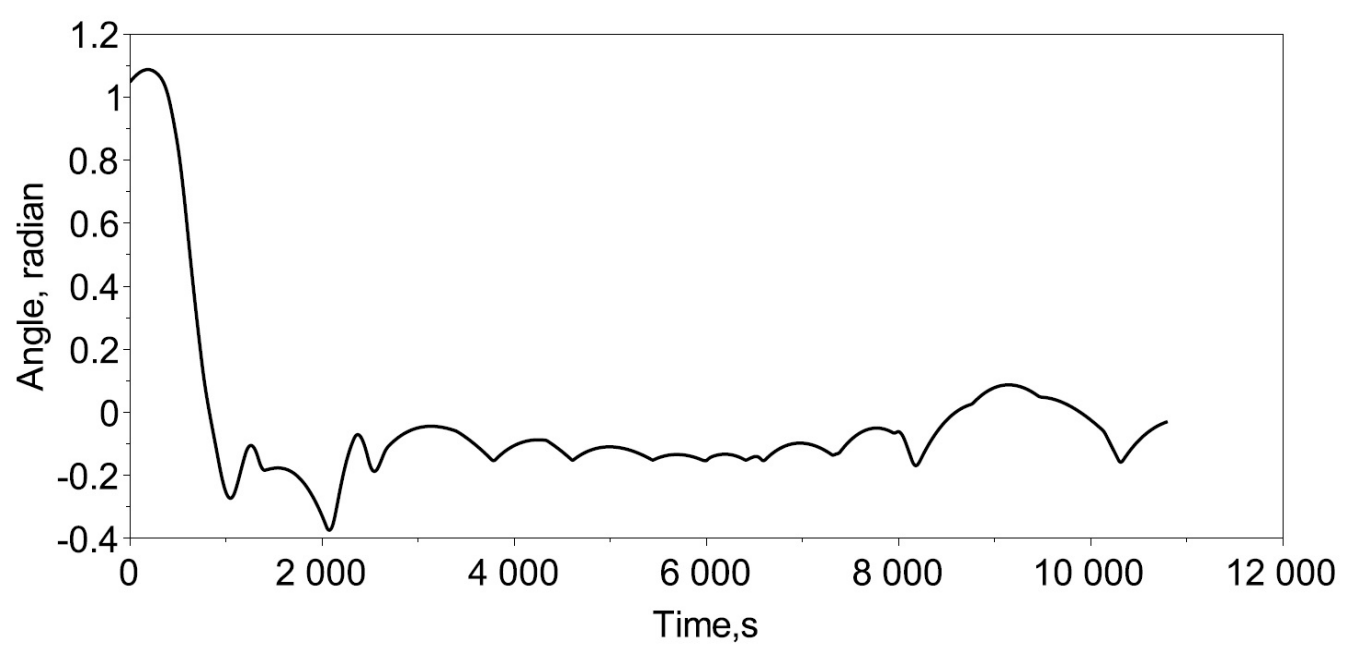

Figure 2 - Stabilization by yaw

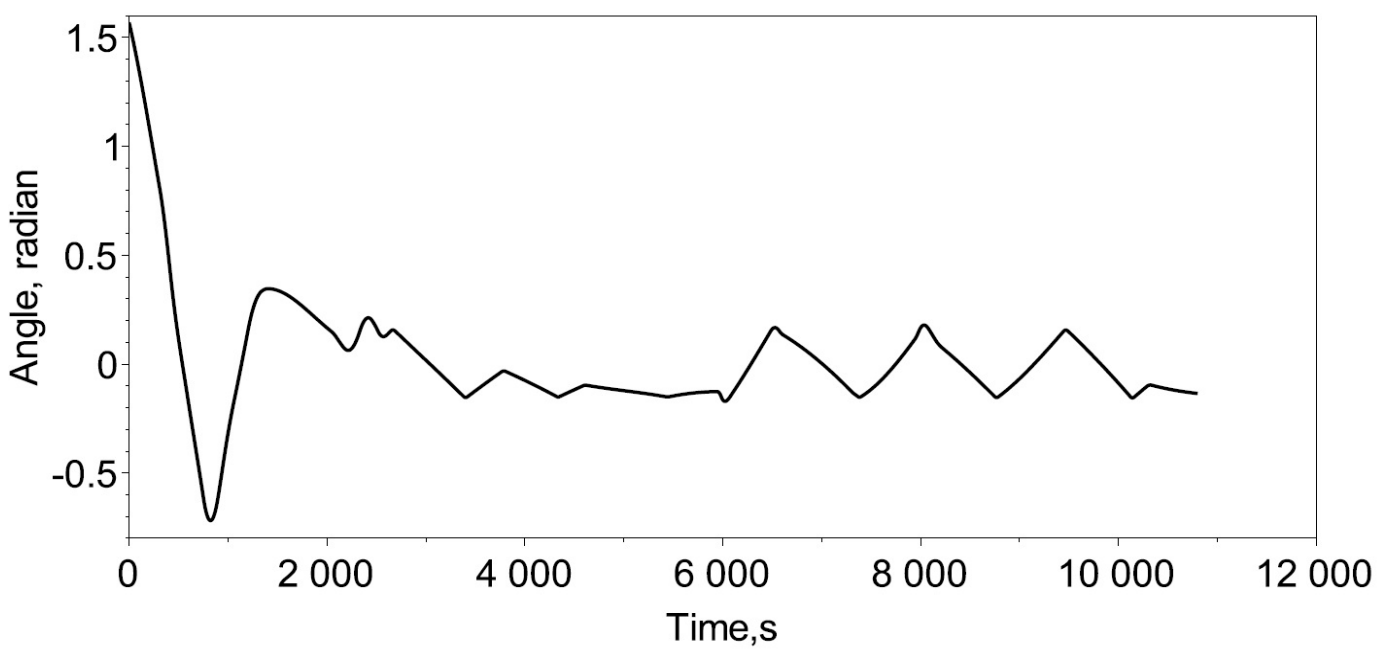

Figure 3 - Stabilization by roll

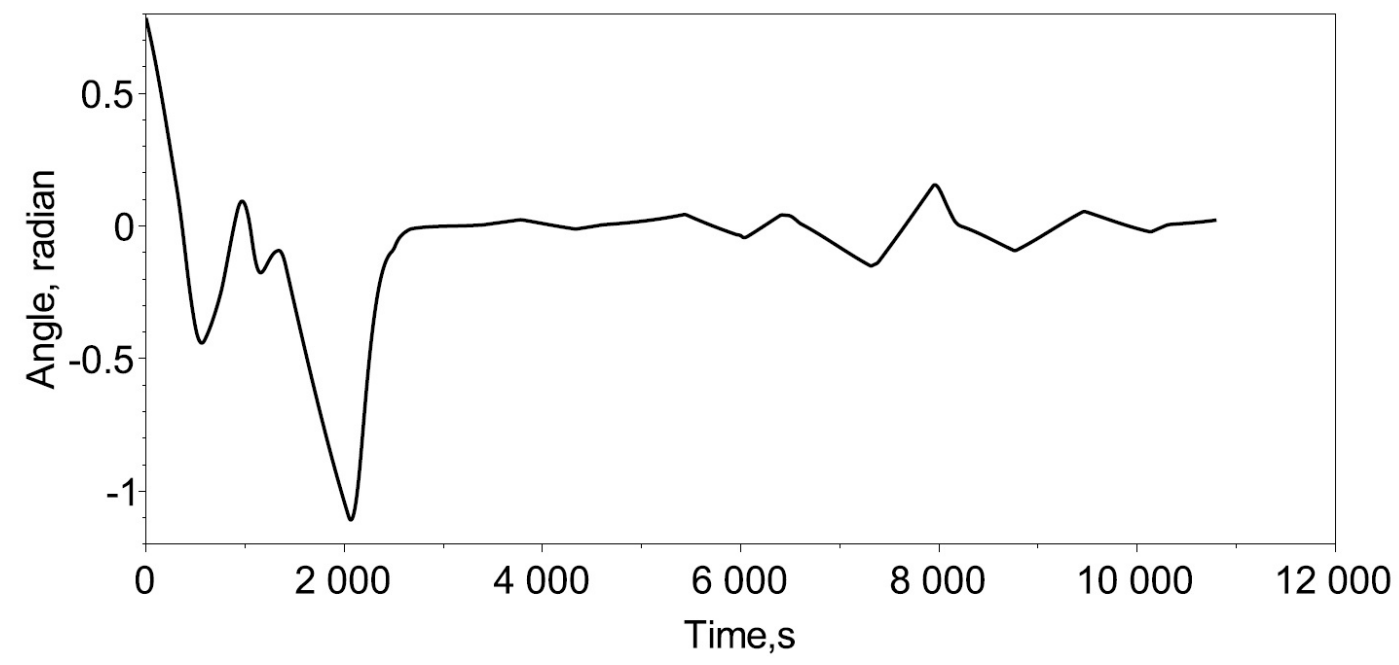

Figure 4 - Stabilization by pitch 
«Системні технологіï» 6 (125) 2019 «System technologies»

Considering, the fact the magnetorquers is the electromagnets, the magnetic dipole moment is calculated by:

$$
p_{m}=I \cdot S \cdot N
$$

where $I$ - the value of supply current for electromagnet;

$S$ - cross section area of the coil;

$N$ - number of turns.

So, the energy consumption of on-board energy can be calculated with using classical formula for electrical energy:

$$
W=U \cdot I \cdot t_{\text {work }}
$$

where $U$ - the value of supply voltage for electromagnet;

$t_{\text {work }}$ - the time of magnetorquers work.

Thus, the full consumption of on-board electrical energy with using formulas (11) and (12) was calculated during simulation and amounted to $0.00107 \mathrm{kWh}$ per the period of control. In turn, when using approach of classic continuous control, the consumption of on-board electrical energy is about $0.04 \mathrm{kWh}$ for magnetorquers of the same class. Thereby, it can be concluded that the consumption of on-board electrical energy during using of mobile control law more than when using devices with rotating permanent magnets in [7], but significantly less than during using approaches of continuous control.

Based on this, mobile control methods can be used for spacecraft that cannot be equipped with devices with rotating permanent magnets, which extends the boundaries of the effective use of aeromagnetic deorbiting systems.

Conclusions. 1. The synthesis of mobile control law for stabilization of spacecraft with the aeromagnetic deorbiting system has been carried out in this research. With using of linear regulator, nonlinear transformation and algorithms of mobile control, the mobile control law for stabilization by magnetorquers was developed.

2. Computer modeling has shown the feasibility of using the synthesized law of mobile control to stabilize the spacecraft with aeromagnetic deorbiting system in long-term deorbiting missions. The use of this control law has shown sufficient values of stability and quality of control to ensure rough stabilization, which meets the conditions of the task. 
«Системні технологіï» 6 (125) 2019 «System technologies»

3. Consumptions of on-board electrical energy significantly less than during using approaches of continuous control. That's why, mobile control methods can be used in long-term deorbiting missions which extends the boundaries of the effective use of aeromagnetic deorbiting systems.

\section{REFERENCES}

1. Paliy A. S. Methods and means of removing spacecraft from working orbits (state of the problem) // Teh. Meh. (in Russian). - 2012. - No. 1. - P. 94 - 102. 2. Orbital Debris Quarterly News. National Aeronautics and Space Administration (Internet source). - 2019. - Vol. 23, Iss. 4. - URL: https://orbitaldebris.jsc.nasa.gov/quarterly-news/pdfs/odqnv23i4.pdf

3. Alpatov A. P., Holdshtein Yu. M. On the choice of the ballistic parameters of an on-orbit service spacecraft // Tekhicheskaya Mekhanika. - 2019. - Vol. 1. P. $25-37$.

4. Pikalov R.S., Yudincev V.V. Review and selection of means of deorbiting of large space debris (in Russian) // Trydu MAI. - 2018. - No. 100. URL: http://trudymai.ru/upload/iblock/239/Pikalov_YUdintsev_rus.pdf?lang=r $\mathrm{u}$ \&issue $=100$.

5. Dron N. M., Horolsky P. G., Dubovik L. G. Ways of reduction of technogenic pollution of the near-earth space // Naukovyi Visnyk Natsionalnoho hirnychoho universytetu. - 2014. - Issue 3. - P. 125-130.

6. Svorobin D. S., Fokov A. A., Khoroshylov S. V. Feasibility analysis of aerodynamic compensator application in noncontact space debris removal (in Russian) // Aviatsionno-Kosmicheskaya Tekhnika i Tekhnologiya. - 2018. -No. 6. - Pp. 4 - 11. doi: 10.32620/aktt.2018.6.01

7. Lapkhanov E. Khoroshylov S. Development of the aeromagnetic space debris deorbiting system // Eastern-European Journal of Enterprise Technologies. - 2019. - Vol. 5. Iss. 5(101). - P. 30 - 37. DOI: 10.15587/17294061.2019.179382

8. Dron' M., Golubek O. , Dubovik L., Dreus A., Heti K. Analysis of the Ballistic Aspects of the Combined Method of Deorbiting Space Objects From the NearEarth Orbits // Eastern-European Journal of Enterprise Technologies. - 2019. - № 2/5 (98). P. 49 - 54. DOI: 10.15587/1729-4061.2019.161778. 
«Системні технології» 6 (125) 2019 «System technologies»

9. Szabolcsi R. Pole placement technique applied in unmanned aerial vehicles automatic flight control systems design // Land Forces Academy Review. 2018. - Vol. XXIII, No 1(89). - P. 88 - 98. DOI: 10.2478/raft-2018-0011

10. Parshukov A. N. Methods of synthesis of modal regulators [In Russian]: [textbook. allowance for universities in the field of training. 220200 "Automation and control in the Ural Federal District"] // Tyumen Publishing House. state Oil and Gas University. - 2009. - 83 p.

11. Kurdyukov A.P., Timin V.N. Synthesis of a robust $\mathrm{h}$ _inf-controller for controlling an energy boiler plant [In Russian] // Control of large systems: proceedings. 2009. From $179 \neg 214$. URL: https://cyberleninka.ru/article /v/sintez-robastnogo-h-inf-regulyatoradlyaupravleniya-energeticheskoykotelnoy-ustanovkoy

12. Alpatov A.P. Spacecraft dynamics (in Russian) // Publishing "Naukova dumka". - 2016. - 488 p.

13. Dynamics of spacecraft with magnetic control systems: monography (in Russian) / Alpatov A. P. and others., M: Mashinostroenie, 1978. 200 p.

14. Maslova, A.I., Pirozhenko, A.V. Orbit changes under the small constant deceleration (in Russian) // Space Sci.\&Technol. - 2016. V. 6, No 22. - P. 20 24. doi.org/10.15407/knit2016.06.020

15. Fortescue P., Stark J., Swinerd G. Spacecraft systems engineering // John Wiley \& Sons Ltd. Chichester. - 2011. - 724 p.

16. ECSS-E-ST-10-04C. Space engineering, Space environment. Approved from 15 November 2008. Noordwijk : ECSS Secretariat, ESA-ESTEC, Requirements \& Standards Division, 2008. - 198 p.

Received 05.12.2019. Accepted 09.12.2019.

Застосування методів рухомого керування для стабілізації космічного апарату 3 аеромагнітною системою відведення

Пошук оптимальних алгоритмів керування космічними апаратами є однією із ключових задач ракетно-космічної техніки. Враховуючи певні обмеження та вимоги в деяких космічних місіях, здійснюється вибір певних виконавчих пристроїв для космічного апарату і проводиться синтез відповідного закону керування. Однією з таких космічних місій $\epsilon$ забезпечення кутової стабілізації руху відпрацьованого космічного апарату, з аеромагнітною системою відведення. Стабілізація кутового руху космічного апарату потрібна для орієнтації аеродинамічного елементу, перпендикулярно до вектору динамічного потоку атмосфери з метою збільшення аеродинамічної сили гальмування. Основним критерієм оптимізації в цій місії є мінімізація споживання бортової електричної енергії, яка необхідна для керування кутовим рухом. Оригінальна конструкція аеромагнітної системи від- 


\section{«Системні технології» 6 (125) 2019 «System technologies»}

ведення складається з аеродинамічного плоского вітрильного елементу та виконавчих керуючих пристроїв з постійними магнітами. Однак далеко не всі космічні апарати може бути оснащено додатковими керуючими пристроями з постійними магнітами. Так, з метою розширення застосування аеромагнітної системи відведення пропонується застосування додаткового ресурсу електромагнітних керуючих органів.

Метою статті є пошук закону керування, який забезпечує мінімальне споживання електричної бортової енергії електромагнітними виконавчими пристроями під час тривалої операції по відведенню відпрацьованого космічного апарату. в досліджені, для забезпечення мінімальних витрат бортової енергії, пропонується використання методів рухомого керування для орієнтації космічного апарату з аеромагнітною системою відведення. Комп'ютерне моделювання орбітального руху космічного апарату з аеромагнітною системою відведення демонструє ефективність використання запропонованих методів рухомого керування кутовим рухом, що реалізуються за допомогою електромагнітних пристроїв - магнетторків. Також, було показано, що при використанні методу рухомого керування, споживання бортової електричної енергії значно менше, ніж при класичному підході. Визначено переваги та недоліки.

The use of mobile control methods for stabilization of a spacecraft with aeromagnetic deorbiting system

The analysis and synthesis of the control law of a spacecraft with an aeromagnetic deorbiting system with using the methods of mobile control is carried out. Using computer simulation, system stability and control quality were analyzed. Based on the comparison of the on-board energy consumptions in the application of mobile control and the classical approach, the feasibility of applying the methods of mobile control for rough stabilization of the spacecraft with an aeromagnetic diversion system has been substantiated.

Алпатов Анатолій Петрович - Член-кореспондент НАН України, доктор технічних наук, завідувач відділу, Відділ системного аналізу і проблем керування, Інститут технічної механіки Національної академії наук України та Державного космічного агентства України.

Лапханов Ерік Олександрович - Аспірант, Відділ системного аналізу і проблем керування, Інститут технічної механіки Національної академії наук України та Державного космічного агентства України.

Алпатов Анатолий Петрович - член-корреспондент НАН Украины, доктор технических наук, заведующий отделом, Отдел системного анализа и проблем управления, Институт технической механики Национальной академии наук Украины и Государственного космического агентства Украины.

Лапханов Эрик Александрович - аспирант, Отдел системного анализа и проблем управления, Институт технической механики Национальной академии наук Украины и Государственного космического агентства Украины.

Anatolii Alpatov - Corresponding Member of NAS of Ukraine, Doctor of Technical Sciences, Department Head, Department of system analysis and control problems, Institute of technical mechanics of National academy of science of Ukraine and State space agency of Ukraine.

Erik Lapkhanov - Postgraduate student, Department of system analysis and control problems, Institute of technical mechanics of National academy of science of Ukraine and State space agency of Ukraine. 